Provided for non-commercial research and education use. Not for reproduction, distribution or commercial use.

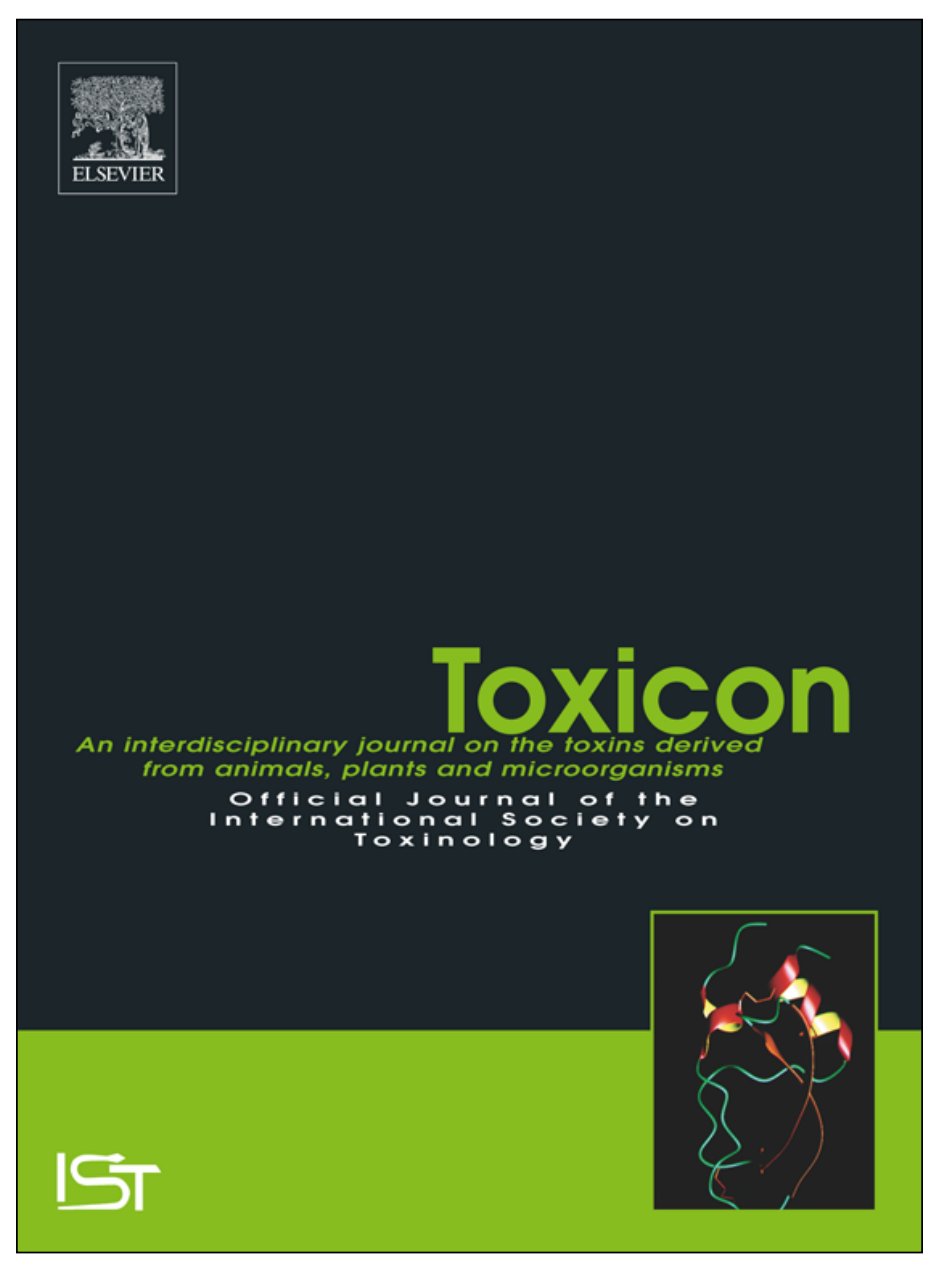

(This is a sample cover image for this issue. The actual cover is not yet available at this time.)

This article appeared in a journal published by Elsevier. The attached copy is furnished to the author for internal non-commercial research and education use, including for instruction at the author's institution and sharing with colleagues.

Other uses, including reproduction and distribution, or selling or licensing copies, or posting to personal, institutional or third party websites are prohibited.

In most cases authors are permitted to post their version of the article (e.g. in Word or Tex form) to their personal website or institutional repository. Authors requiring further information regarding Elsevier's archiving and manuscript policies are encouraged to visit:

http://www.elsevier.com/authorsrights 


\title{
Next Generation Sequencing and mass spectrometry reveal high taxonomic diversity and complex phytoplankton-phycotoxins patterns in Southeastern Pacific fjords
}

\author{
Mario Moreno-Pino ${ }^{\mathrm{a}}$, Bernd Krock ${ }^{\mathrm{b}}$, Rodrigo De la Iglesia ${ }^{\mathrm{c}}$, Isidora Echenique-Subiabre ${ }^{\mathrm{a}}$, \\ Gemita Pizarro $^{\mathrm{d}}$, Mónica Vásquez ${ }^{\mathrm{c}}$, Nicole Trefault ${ }^{\mathrm{a}, *}$ \\ a GEMA Center for Genomics, Ecology and Environment, Universidad Mayor, Camino La Pirámide 5750, Santiago, Chile \\ ${ }^{\mathrm{b}}$ Alfred-Wegener Institute for Polar and Marine Research, Am Handelshafen 12, 27570 Bremerhaven, Germany \\ ${ }^{\mathrm{c}}$ Department of Molecular Genetics and Microbiology, Pontificia Universidad Católica de Chile, Alameda 340, Santiago, Chile \\ ${ }^{\mathrm{d}}$ Instituto de Fomento Pesquero, Enrique Abello 0552, Punta Arenas, Chile
}

\section{A R T I C L E I N F O}

\section{Keywords:}

Fjord systems

Next Generation Sequencing (NGS)

Phytoplankton

Lipophilic toxins

Harmful Algal Bloom (HAB)

\begin{abstract}
A B S T R A C T
In fjord systems, Harmful Algal Blooms (HABs) not only constitute a serious problem when affecting the wildlife and ecosystems, but also human health and economic activities related to the marine environment. This is mostly due to a broad spectrum of toxic compounds produced by several members of the phytoplankton. Nevertheless, a deep coverage of the taxonomic diversity and composition of phytoplankton species and phycotoxin profiles in $\mathrm{HAB}$ prone areas are still lacking and little is known about the relationship between these fundamental elements for fjord ecosystems. In this study, a detailed molecular and microscopic characterization of plankton communities was performed, together with an analysis of the occurrence and spatial patterns of lipophilic toxins in a HAB prone area, located in the Southeastern Pacific fjord region. Microscopy and molecular analyses based on the 18S rRNA gene fragment indicated high diversity and taxonomic homogeneity among stations. Four toxigenic genera were identified: Pseudo-nitzschia, Dinophysis, Prorocentrum, and Alexandrium. In agreement with the detected species, liquid chromatography coupled with mass spectrometry revealed the presence of domoic acid (DA), pectenotoxin-2 (PTX-2), dinophysistoxin-2 (DTX-2), and 13-desmethyl spirolide C (SPX-1). Furthermore, a patchy distribution among DA in different net haul size fractions was found. Our results displayed a complex phytoplankton-phycotoxin pattern and for the first time contribute to the characterization of high-resolution phytoplankton community composition and phycotoxin distribution in fjords of the Southeastern Pacific region.
\end{abstract}

\section{Introduction}

Fjords are semi-closed coastal ecosystems and represent one of the most valuable systems on the planet, offering a wide array of ecosystem services to wildlife and humans (Iriarte et al., 2010). Unfortunately, in the last few decades an apparent increase in the frequency and extension of coastal areas affected by toxic Harmful Algal Blooms (HABs), has occurred (Berdalet et al., 2017).

The Southeastern fjords and channels from southern Chile comprise a vulnerable region for HABs and over the years have been characterized in terms of the composition of phytoplankton species (Alves-deSouza et al., 2008; Avaria, 2008; Avaria et al., 2003; Iriarte et al., 2001). However, plankton community structure at a high resolution, together with sufficient coverage for a comprehensive description of their diversity, remains largely unexplored. In this region, several classes of phycotoxins produced by phytoplankton groups and their associated shellfish poisoning syndromes have been documented (Alves-de-Souza et al., 2014; Blanco et al., 2005). Phycotoxins consist of a broad spectrum of compounds, including the hydrophilic toxins domoic acid (DA) and paralytic shellfish toxins (PSTs), and the lipophilic toxins okadaic acid (OA), dinophysistoxins (DTXs), pectenotoxins (PTXs), yessotoxins (YTXs), gymnodimines (GYMs), azaspiracids (AZAs) and spirolides (SPXs) (Berdalet et al., 2016). While PSTs are the longest known and best characterized phycotoxins, lipophilic toxins are more diverse and lesser studied. Phycotoxins are produced by several phytoplankton species, such as dinoflagellates (e.g. Alexandrium spp., Dinophysis spp., Karenia spp.) and diatoms (e.g. Pseudo-nitzschia spp.) (Rasmussen et al., 2016), differing in their mode of action and poisoning syndrome to humans (Berdalet et al., 2016; Rasmussen et al., 2016). In fjords of Tierra del Fuego, Trefault et al. (2011) identified

\footnotetext{
* Corresponding author

E-mail address: nicole.trefault@umayor.cl (N. Trefault).
} 
several phycotoxins revealing the appearance of newly identified compounds, yet the spatial resolution applied was not enough for a complete description of the area nor the identification of the producer species.

Toxic HAB species detection has been traditionally made by direct microscopy observations - which cannot always be appropriate as toxic and non-toxic species can belong to the same genus with indistinguishable morphological features (Toebe et al., 2013) - and/or based on toxin detection. This later approach is based on modern analytical techniques, such as liquid chromatography coupled to tandem mass spectrometry (LC-MS/MS) (Hess, 2010), which allows the detection of individual compounds, with specific toxicities (Krock et al., 2009a, 2008). On the other hand, studies utilizing Next Generation Sequencing (NGS) technologies offer an enormous potential for identification of (toxigenic) planktonic organisms due to their high resolution and coverage (Dzhembekova et al., 2017).

The main aims of this work were (1) to obtain a deep coverage of the taxonomic diversity and community composition of plankton species, with a special focus on phytoplankton, in the area between the Strait of Magellan and the Cape Horn, (2) to characterize this HAB prone area in terms of its phycotoxin diversity, profiles and spatial patterns, and (3) to relate (phyto)plankton community composition with the identified phycotoxin profiles.

\section{Materials and methods}

\subsection{Sampling procedure}

Sampling was performed during the "CIMAR 16 Fiordos" expedition aboard the $R / V$ "Abate Molina", from October 11th to November 19th, 2010, and included the fjords region between the Strait of Magellan and Cape Horn (Chile), with 17 sampling station (Fig. 1 and Table S1).

Seawater samples (at $5 \mathrm{~m}, 10 \mathrm{~m}$ and $20 \mathrm{~m}$ depth) were collected from Niskin bottles. Aliquots of each depth were fixed and used for microscopy (see below). Additionally, duplicate surface seawater samples ( $5 \mathrm{~L}, 5 \mathrm{~m}$ depth) were pre-filtered through a $180 \mu \mathrm{m}$ mesh and cells were retained on the $3 \mu \mathrm{m}$ diameter pore polycarbonate filters (TSTP04700, Millipore, Ireland). One filter of each fraction was used for DNA analysis and the other for toxin analysis. Plankton cell concentrates were collected by vertical plankton net $(23 \mu \mathrm{m})$ tows from a depth of $20 \mathrm{~m}$ to the surface. A total of 17 phytoplankton net samples were adjusted to a volume of $500 \mathrm{~mL}$ of filtered seawater. Two $250 \mathrm{~mL}$ aliquots were size-fractionated using a peristaltic pump (Masterflex 7553-85, Cole-Parmer, USA) and nylon filters of 180,55 , and $20 \mu \mathrm{m}$ pore diameter (Millipore, Ireland). One set of fractions was used for molecular analysis and the other for determination of toxin profiles. All filters were kept frozen at $-20{ }^{\circ} \mathrm{C}$ until further processing in the laboratory.

For qualitative plankton analysis by microscopy, plankton net aliquots of $50 \mathrm{~mL}$ were fixed with neutralized formalin (3\% final concentration). For quantitative plankton analysis by microscopy, aliquots of $100 \mathrm{~mL}$ of each depth from the Niskin bottles were fixed with acidic Lugol's solution (1\% final concentration). Samples for microscopy were kept in the dark until microscopy identification and quantification.

\subsection{Oceanographic data}

Water column temperature, salinity, and dissolved oxygen were routinely measured on each sampling station using a SeaBird 19 CTDO (Washington, USA). The data at $5 \mathrm{~m}$ depth are shown in Table S1.

\subsection{Microscopy}

For qualitative plankton analysis, samples were visualized under an inverted microscope $(40 \times$, Olympus, CKX41) and relative abundance of toxic species was calculated. Cells of Alexandrium catenella, A. ostenfeldii, Dinophysis acuta, D. acuminata, Protoceratium reticulatum, Pseudo-nitzschia seriata complex and $P$. delicatissima complex were counted in $0.1 \mathrm{~mL}$ aliquots of sedimented sample, under an $18 \times 18 \mathrm{~mm}$ cover slide (three replicates). Cell numbers were expressed in a ten-levels abundance scale (Table S2), according to Guzmán et al. (2013).

For quantitative plankton analysis, samples were enumerated with a light microscope $(20 \times$, Olympus, BX41) using sedimentation chambers with a volume defined based on the plankton density of each sample, according to Utermöhl (1958). At least 26 cells of the dominant taxa were counted in one or more strips of the chamber. The whole chamber bottom was also scanned to count large and sparse species. Results were expressed integrating values from the water column between the surface and $20 \mathrm{~m}$ depth, as cell number per $\mathrm{L}$.

\subsection{DNA extractions}

Filter-handling steps were performed under sterile conditions. Filters were cut into small pieces and incubated in lysis buffer (TE1x/ $\mathrm{NaCl} 0.15 \mathrm{M}$ ), with $10 \% \mathrm{SDS}$ and $20 \mathrm{mg} \mathrm{mL}^{-1}$ proteinase $\mathrm{K}$ at $37^{\circ} \mathrm{C}$ for $1 \mathrm{~h}$. DNA was extracted using $5 \mathrm{M} \mathrm{NaCl}$ and $\mathrm{N}, \mathrm{N}, \mathrm{N}-$

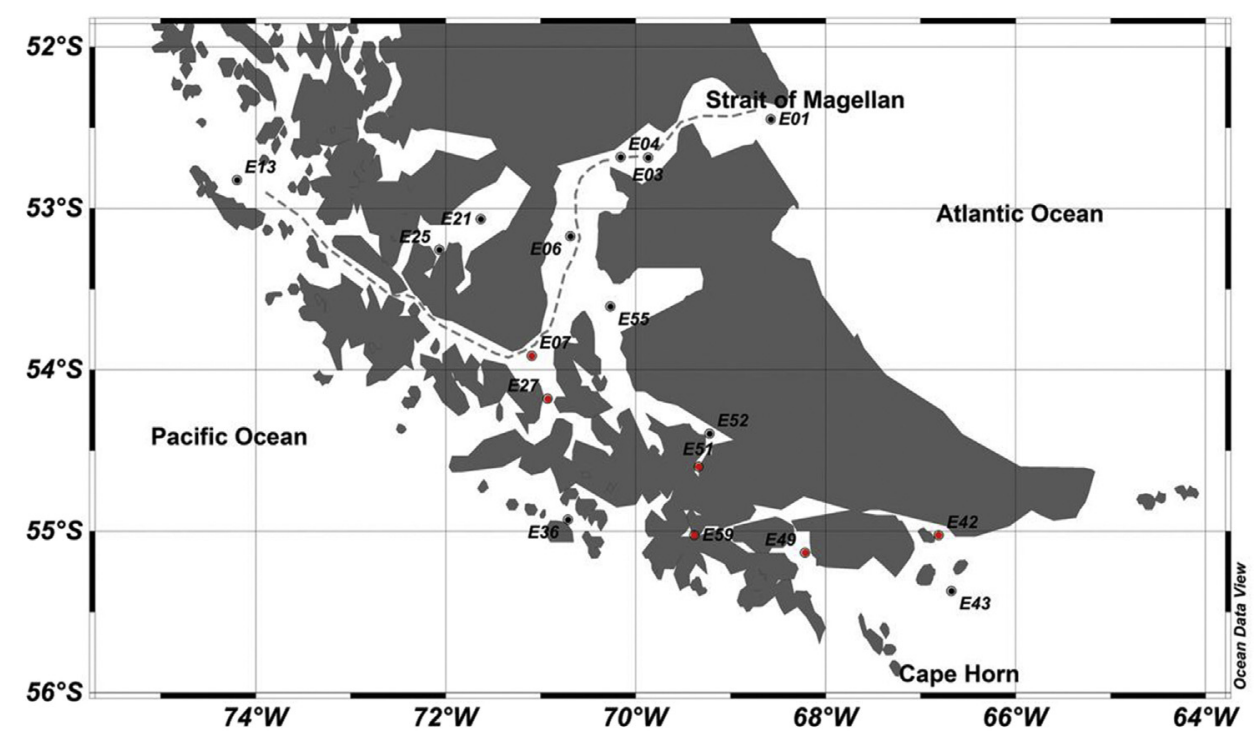

Fig. 1. Map of the study site indicating sampling stations. Samples were taken in the fjords area between the Strait of Magellan (dashed grey line) and Cape Horn, at the continental margin of the South Pacific Ocean. Red circles indicate stations that were selected for molecular diversity and community composition analysis. (For interpretation of the references to colour in this figure legend, the reader is referred to the Web version of this article.) 
trimethylhexadecylammonium bromide (CTAB) extraction buffer $(10 \%$ $\mathrm{CTAB}, 0.7 \% \mathrm{NaCl}$ ) incubated at $65^{\circ} \mathrm{C}$ for $10 \mathrm{~min}$ and protein removal was performed using chloroform-isoamyl alcohol (24:1) (Doyle and Doyle, 1987). DNA was precipitated using ethanol at $-20^{\circ} \mathrm{C}$ for $1 \mathrm{~h}$. The DNA was assessed for integrity by DNA gel electrophoresis on a $0.8 \%$ agarose gel in TAE buffer ( $40 \mathrm{mM}$ Tris-acetate, $1 \mathrm{mM}$ EDTA, $\mathrm{pH}$ 7, 8), quantified using a Quantifluor (Promega) and Quant-iT Picogreen (Invitrogen), and stored at $-20^{\circ} \mathrm{C}$ until further analysis.

\subsection{PCR amplification and Next Generation Sequencing (tag sequences)}

From the 17 sampling stations, six stations were selected for molecular diversity and community composition analysis based on a) toxin diversity: the number of different toxins found at each station (i.e., at least 3), b) the toxin concentration in each fraction and c) DNA availability. This resulted in a total of 13 samples for NGS analyses. For station E7, fractions analyzed were $55-180$ and 3-180 $\mu \mathrm{m}$; for E51 the fraction analyzed was $3-180 \mu \mathrm{m}$; for E27 and E59, fractions were 55-180 and 20-55 $\mu \mathrm{m}$; and for E42 and E49, fractions analyzed were 55-180, 20-55 and 3-180 $\mu \mathrm{m}$. For each sample, the 18S rRNA gene hypervariable region V9 was amplified using the 3-domain primer $1391 \mathrm{f}$ and the eukaryal specific EukBr primer (Amaral-Zettler et al., 2009), following conditions from Earth Microbiome Project (EMP). Illumina primer constructs were obtained from EMP as well (Gilbert et al., 2014). Amplicons were quantified using Q-PCR Library Quant Kit Illumina GA and sequenced using Illumina Miseq (Caporaso et al., 2012). A total of 12 pM of qPCR quantified amplicons pool was sequenced using a 300-cycles Illumina Miseq kit. To increase the sequence detection probability from potentially toxigenic organisms that could be present at very low abundances, sequencing was performed at a high coverage.

\subsection{Sequencing data analysis}

Analyses of sequences were performed using the software Mothur (Schloss et al., 2009). Sequencing reads were assigned to samples according to their barcodes and read 1 and 2 were assembled using make.contigs command. Primers were removed out of Mothur using Cutadapt (Martin, 2011). Sequences less than $100 \mathrm{bp}$ and above $200 \mathrm{bp}$ long, with ambiguous nucleotides and homopolymers longer than $8 \mathrm{pb}$, were removed from further analysis, using screen.seqs. Alignment was computed using align.seqs with the recreated Silva SEED v119 (Quast et al., 2013) as references and sequences that fall out of the median distribution of the alignment were removed (start $=41,778$, end $=43,116$, and minlength $=100$ ). Chimeras were screened with chimera.uchime (Edgar et al., 2011) and removed from further analysis. An initial taxonomic classification was accomplished using classify.seqs against the Protist database version 4.1 (Guillou et al., 2013), to allow removal of the undesirable lineage: taxon = Eukaryota; Opisthokonta; Metazoa. A distance matrix was generated using dist.seqs with a cutoff $=0.1$. This distance matrix was given to the cluster command with a cutoff $=0.03$ to generate $97 \%$ Operational Taxonomical Units (OTUs) similarity threshold, and their classification was accomplished using classify.otu first against SILVA database (data not shown) (Pruesse et al., 2007) and finally against Protist database version 4.1 (Guillou et al., 2013) using a label $=0.03$. Rarefaction curves were obtained using the rarefaction.single command. Ecological indexes (Richness, Shannon's and Evenness diversity indexes) were obtained using summary.single. OTUs formed by 5 or less sequences were removed for further analyses with the remove.rare command.

\subsection{Toxin extraction and LC-MS/MS analysis}

Sample extraction for lipophilic toxin and DA analysis and mass spectral experiments were performed according to Krock et al. (2008). Briefly, plankton concentrates were resuspended in $500 \mu \mathrm{L}$ of methanol and transferred into a FastPrep tube containing $0.9 \mathrm{~g}$ of lysing matrix D. These samples were homogenized by reciprocal shaking at $6.5 \mathrm{~m} \mathrm{~s}^{-1}$ for $45 \mathrm{~s}$ in the FastPrep (Thermo Savant, Illkirch, France) apparatus, and subsequently centrifuged. The supernatant was spin-filtered $(0.45 \mu \mathrm{m})$ and transferred into an autosampler vial for analysis by LC-MS/MS. Mass spectral experiments were performed on a triple quadrupolelinear ion trap hybrid mass spectrometer (AB Sciex, Darmstadt, Germany) coupled to a Model 1100 LC system (Agilent, Waldbronn, Germany). Separation of lipophilic toxins was performed by reversed phase chromatography on a C8 phase. The chromatographic run was divided into 3 periods: 1) 0-8.75 min for DA, 2) $8.75-11.20 \mathrm{~min}$ for GYM and SPXs and 3) $11.20-18 \mathrm{~min}$ for OA, DTXs, PTXs, YTX and AZA-1. Selected reaction monitoring (SRM) experiments were carried out in positive ion. Phycotoxins were quantified by external calibration against standard solutions obtained from the Certified Reference Material program of the Institute of Marine Biology of the National Research Council (IMB-NRC), Halifax, NS, Canada.

\subsection{Similarity-based cluster and statistical analyses}

A non-metric multidimensional scaling (NMDS) was performed to visualize the spatial distribution pattern of the sequenced samples at the genus and species level determined by NGS, after Hellinger transformation of the dataset. Permutational multivariate analysis of variance (PERMANOVA) was further applied to test whether sampling stations and/or fractions were significantly different. NMDS plots and PERMANOVA were computed based on the Bray-Curtis dissimilarity measure. A heatmap with hierarchical clustering was performed on DA concentration among fractions in each sample using d3heatmap (Cheng et al., 2016) and gplots (Warnes et al., 2016) packages. For this, DA concentration values were normalized (centered: subtracting the column means and scaled: dividing the centered columns by their standard deviations), and a matrix was constructed based on the Euclidean distances and clusterization following Ward method. A partial Redundancy Analysis (pRDA) was performed to examine the relative contribution of environmental variables (water column temperature, salinity, and dissolved oxygen) and geographical position on the DA concentrations. NMDS, PERMANOVA, similarity matrices, hierarchical cluster and pRDA were carried out using vegan package (Oksanen et al., 2016) under $R$ language (version 3.3.0 R Core Team, 2014; Vienna, Austria). Only $p<0.05$ were considered statistically significant.

\subsection{Tag sequences accession number}

Tag sequences have been deposited in the National Center for Biotechnology Information (NCBI) Short Read Archive (SRA) under the accession number SRX665285.

\section{Results and discussion}

\subsection{Physical parameters}

Physical parameters of surface waters ( $5 \mathrm{~m}$ depth) monitored at the stations of the study area were relatively homogenous (Fig. 1 and Table S1). The temperature range spanned over $2^{\circ} \mathrm{C}$ from $5.3^{\circ} \mathrm{C}$ at station E51 (Fig. 1) up to $7.4^{\circ} \mathrm{C}$ at station E07. The salinity range was slightly higher ranging from 27.5 PSU at station E51 to 32.5 PSU at station E43. As expected, inner fjord stations with more fresh water input and lesser water exchange with open sea waters showed lower salinities than more marine influenced stations. Oxygen levels ranged from $7.1 \mathrm{mLL}^{-1}$ at station E01, E03, E04, E25 and E52 up to a maximum of $8.1 \mathrm{~mL} \mathrm{~L}^{-1}$ at station E55.

\subsection{Microscopy characterization of (phyto)plankton community}

Phytoplankton net samples were analyzed under microscope for 
Table 1

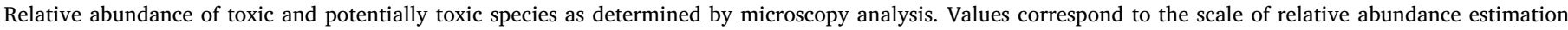

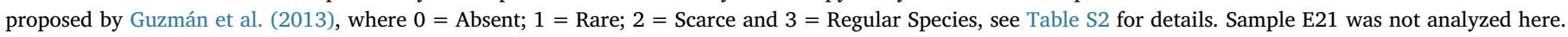

\begin{tabular}{|c|c|c|c|c|c|c|c|}
\hline Station & $\begin{array}{l}\text { Alexandrium } \\
\text { catenella }\end{array}$ & $\begin{array}{l}\text { Dinophysis } \\
\text { acuminata }\end{array}$ & Dinophysis acuta & $\begin{array}{l}\text { Pseudo-nitzschia seriata } \\
\text { complex }\end{array}$ & $\begin{array}{l}\text { Pseudo-nitzschia delicatissima } \\
\text { complex }\end{array}$ & $\begin{array}{l}\text { Protoceratium } \\
\text { reticulatum }\end{array}$ & Alexandrium ostenfeldii \\
\hline E01 & 0 & 0 & 0 & 0 & 0 & 0 & 0 \\
\hline E03 & 0 & 0 & 0 & 1 & 0 & 0 & 0 \\
\hline E04 & 0 & 0 & 0 & 0 & 0 & 0 & 0 \\
\hline E06 & 0 & 0 & 0 & 0 & 0 & 0 & 0 \\
\hline E07 & 2 & 0 & 1 & 1 & 1 & 0 & 0 \\
\hline E13 & 3 & 0 & 0 & 0 & 0 & 1 & 0 \\
\hline E25 & 0 & 1 & 1 & 0 & 0 & 0 & 0 \\
\hline E55 & 0 & 0 & 0 & 0 & 1 & 0 & 1 \\
\hline E52 & 0 & 0 & 0 & 0 & 0 & 0 & 0 \\
\hline E51 & 0 & 0 & 0 & 0 & 0 & 0 & 0 \\
\hline E27 & 2 & 1 & 0 & 2 & 0 & 0 & 1 \\
\hline E36 & 0 & 0 & 0 & 1 & 0 & 0 & 0 \\
\hline E59 & 1 & 1 & 0 & 2 & 0 & 0 & 0 \\
\hline E42 & 0 & 1 & 1 & 0 & 0 & 0 & 1 \\
\hline E43 & 1 & 1 & 0 & 1 & 0 & 0 & 0 \\
\hline E49 & 2 & 1 & 0 & 3 & 0 & 0 & 0 \\
\hline
\end{tabular}

taxonomic composition characterization (i.e., quantitative analysis) (Table S3). Diatoms dominated almost all stations, with relative abundances of $31.3 \% \pm 28.1$ (average by sampling station \pm SD) of Chaetoceros spp. and $21.7 \% \pm 15.7$ of Thalassiosira spp. The dominance of diatoms is quite typical in the sampling area and throughout the sampling period (spring) (Alves-de-Souza et al., 2008; Iriarte et al., 2001). Station E52 was the exception, in which undetermined dinoflagellates represented $100 \%$ of the sample. In addition, the highest cell concentrations were observed for Pseudo-nitzschia spp. (maximum of 415,112 cells per $\mathrm{L}$ ) at station $\mathrm{E} 49$, representing $64.2 \%$ of the sample.

The relative abundance of observed toxic and potentially toxic species (i.e., qualitative analysis) ranged between rare and regular (Table 1), consistent with previous reports for the area (Alves-de-Souza et al., 2008; Avaria, 2008; Avaria et al., 2003). P. seriata complex was the most frequently observed species - detected in 7 of the 16 analyzed stations - while A. catenella was observed in 6 stations. D. acuminata also occurred at 6 stations but only in rare abundances.

\subsection{Phytoplankton composition determined by NGS}

After quality filtering and pre-processing of the dataset, a total of $15,435,067$ reads were obtained from 13 samples taken at six stations consisting of 3-180 $\mu \mathrm{m}$ fraction of surface seawater samples and/or the $20-55 \mu \mathrm{m}$ and/or $55-180 \mu \mathrm{m}$ fractions of net hauls samples. A summary of the sequencing data is shown in Table 2. Rarefaction curves indicated that sampling size allowed deep coverage of plankton diversity (Fig. S1). Diversity Shannon indexes ranged between 2.5 and 4.6, revealing important richness and evenness within samples. This was confirmed by evenness indexes between 0.3 and 0.6 (Table 2). Overall, Stramenopiles, Alveolata and Archaeplastida captured most of the sequences, with relative abundances of $41.5 \% \pm 20.2$ (average by sample \pm SD), $39.5 \% \pm 18.5$ and $12.7 \% \pm 15$ of total reads respectively. The percentage of unclassified OTUs (reflected as no blast hit) was unusually low $(0.007 \%)$.

Concerning the heterotrophic community (Fig. 2a) important groups in marine systems were found: Fungi $(41.5 \% \pm 1.1$ average by sample within heterotrophic community \pm SD), for example, are highly diversified with filamentous, yeast and chytrid members described in parasitic associations with marine mammals or phytoplankton (diatoms and dinoflagellates) (Park et al., 2004; Richards et al., 2012). Ciliophora $(33.1 \% \pm 2.5)$ was mostly represented by members of the genera Bryometopus, Strombidium and Mesodinium. This latter has been already described in co-occurrence with Dinophysis in a costal Inlet of Finland (Sjöqvist and Lindholm, 2011) and recently in the Chilean fjord of Reloncaví (Alves-de-Souza et al., 2014). In addition, some stations presented important relative abundances of Cercozoa (between 6.7 and $32.5 \%$ of the reads). In this study, the predatory genus Cryothecomonas $(10.8 \% \pm 6.7$ average by sample within cercozoan genera) was the second most abundant after Protaspa (data not shown). This element is noteworthy, given that a phagocytic activity against diatoms, particularly Guinardia, was reported in this group (Drebes et al., 1996). In fact, Guinardia was also detected in our study (Fig. 3b; 9.5\% \pm 10.6 read average \pm SD within diatom reads).

The analysis of photosynthetic community revealed two dominant

Table 2

Summary of sequencing data obtained from next-generation sequencing of 18S rRNA gene V9 hypervariable region and Alpha-diversity indexes. OTUs, Operational Taxonomic Units.

\begin{tabular}{|c|c|c|c|c|c|c|c|}
\hline Sample name & Station & Size fraction & Number of initial reads & Number of final reads & Number of identified OTUs & Shannon index $(H)$ & Evenness index $(J)$ \\
\hline E07.3 & E07 & $3-180 \mu \mathrm{m}$ & $1,067,681$ & 394,367 & 4051 & 4.37 & 0.53 \\
\hline E07.55 & E07 & $55-180 \mu \mathrm{m}$ & $1,734,848$ & 802,393 & 4572 & 2.62 & 0.31 \\
\hline E51.3 & E51 & $3-180 \mu \mathrm{m}$ & $1,150,465$ & 486,845 & 3758 & 3.94 & 0.48 \\
\hline E27.20 & E27 & $20-55 \mu \mathrm{m}$ & $1,368,497$ & 606,518 & 5338 & 4.14 & 0.48 \\
\hline E27.55 & E27 & $55-180 \mu \mathrm{m}$ & $1,193,973$ & 300,572 & 3863 & 3.59 & 0.43 \\
\hline E59.20 & E59 & $20-55 \mu \mathrm{m}$ & $1,752,334$ & 801,14 & 6529 & 4.16 & 0.47 \\
\hline E59.55 & E59 & $55-180 \mu \mathrm{m}$ & 844,651 & 194,37 & 2609 & 3.50 & 0.44 \\
\hline $\mathrm{E} 42.3$ & $\mathrm{E} 42$ & $3-180 \mu \mathrm{m}$ & $1,055,451$ & 360,243 & 4594 & 4.57 & 0.54 \\
\hline $\mathrm{E} 42.20$ & E42 & $20-55 \mu \mathrm{m}$ & $1,041,205$ & 396,073 & 3895 & 2.48 & 0.30 \\
\hline E42.55 & $\mathrm{E} 42$ & $55-180 \mu \mathrm{m}$ & $1,290,773$ & 781,122 & 5361 & 3.77 & 0.44 \\
\hline E49.3 & E49 & $3-180 \mu \mathrm{m}$ & $1,226,427$ & 420,71 & 4076 & 4.63 & 0.56 \\
\hline E49.20 & E49 & $20-55 \mu \mathrm{m}$ & 583,895 & 98,461 & 1542 & 2.55 & 0.35 \\
\hline E49.55 & E49 & $55-180 \mu \mathrm{m}$ & $1,124,867$ & 286,876 & 3262 & 3.01 & 0.37 \\
\hline Total & & & $15,435,067$ & $5,929,690$ & & & \\
\hline
\end{tabular}



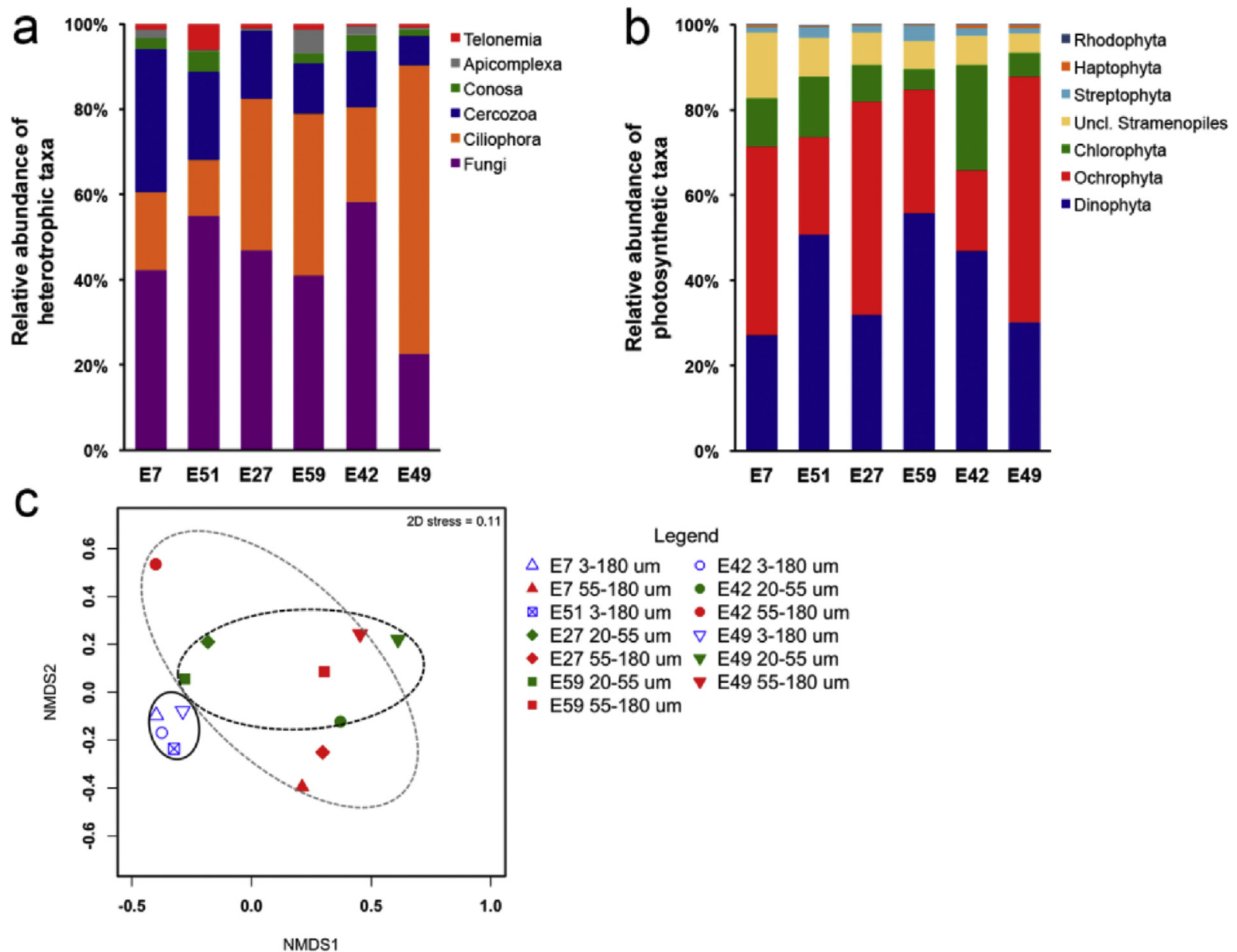

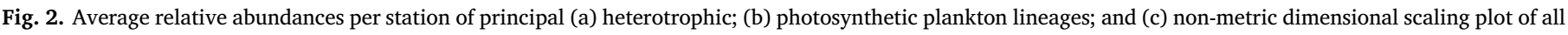

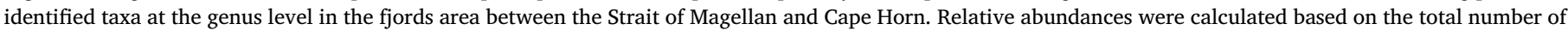

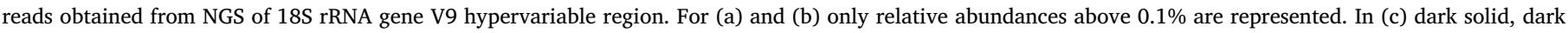
dashed and grey dashed ellipses indicate 70\%, 50\% and 45\% Bray-Curtis similarity, respectively.

taxa over all sampling stations, Dinophyta $(40.6 \% \pm 11.6$ average within photosynthetic community \pm SD) and Ochrophyta $(36.8 \% \pm 13.4)$ (Fig. 2b), while members of Chlorophyta, unclassified Stramenopiles and Streptophyta represented $11.6 \%, 8.3 \%$, and $2 \%$, respectively. Within each of the above-mentioned phytoplankton groups, members of Dinophyceae $(91.2 \% \pm 1.4$ average by sample), Bacillariophyta $(87.3 \% \pm 11.6)$, Mamiellophyceae $(63.6 \% \pm 26.8)$, MAST $(49.1 \% \pm 26.9)$ and Embryophyceae $(98.2 \% \pm 2.9)$ were the most abundant. Mamiellophyceae was mostly represented by the typical marine picoplanktonic genera, Bathycoccus, Micromonas and Ostreococcus, that have already observed in coastal areas worldwide (Vaulot et al., 2008) and also from the South Pacific Ocean (Vaulot et al., 2012) and Antarctic coastal waters (Egas et al., 2017). While these genera were observed in all the stations and fractions, size overlapping may be associated to aggregation and/or particle attachment (Larsen et al., 2008). Furthermore, their detection as prey DNA within higher size predators cannot be excluded (Massana, 2011). Among MAST, members from sub-clades 1C, 9A and 12D were the most abundant.

Unfortunately, available NGS studies by this approach in fjord systems are still scarce to allow comparing our dataset to existing data. Metagenomic and tag sequencing approaches had been restricted to bacterial communities in microbial mats from Comau fjords in the Chilean Patagonia (Ugalde et al., 2013) or to phytoplankton communities from the arctic fjords using a different marker (LSU rRNA D1/D2 region) than our study (Elferink et al., 2017). The microeukaryote diversity, found in the present study, was widespread among stations as found in surveys in other oceanographic regions (Amaral-Zettler et al., 2009; Pawlowski et al., 2011).

NMDS analysis performed at genus level (Fig. 2c) revealed a statistically significant clustering of samples according to the sample type, i.e., seawater versus phytoplankton net samples (PERMANOVA, $p=0.01$ ), without clustering by sampling station. This analysis was also performed separately among heterotrophic and photosynthetic genera, giving similar results (PERMANOVA sample type: heterotrophic $p=0.004$; photosynthetic $p=0.007$, data not shown).

As known toxigenic phytoplankton belong to taxa of Dinophyceae (dinoflagellates) and Bacillariophyta (diatoms), the most abundant genera of these two groups are shown in Fig. 3a and b, respectively.

The majority of the sequences were assigned to specific genera with 78 dinoflagellates and 87 diatom genera identified. In the case of Dinophyceae, reads were assigned mostly to Karenia $(34.4 \% \pm 23.8$ average of dinoflagellate reads by sample \pm SD) and Alexandrium $(19.2 \% \pm 14.5)$ (Fig. 3a), both known as toxigenic genera, however $14.3 \%$ remained as unclassified Dinophyceae. Regarding Bacillariophyta (Fig. 3b), mainly two genera were the most prominent, Thalassiosira ( $44.8 \% \pm 26.5$ average of diatom reads by sample \pm SD) and Chaetoceros $(26.7 \% \pm 25.9)$. Among the other detected toxigenic genera were Gonyaulax, Prorocentrum, Dinophysis, Karlodinium, and Pseudo-nitzschia (Table S4). The relative abundance of these OTUs, measured as number of assigned reads, was very low (in the range of $2.5 \%$ of total reads for Alexandrium and $0.2 \%$ for Pseudo-nitzschia), 

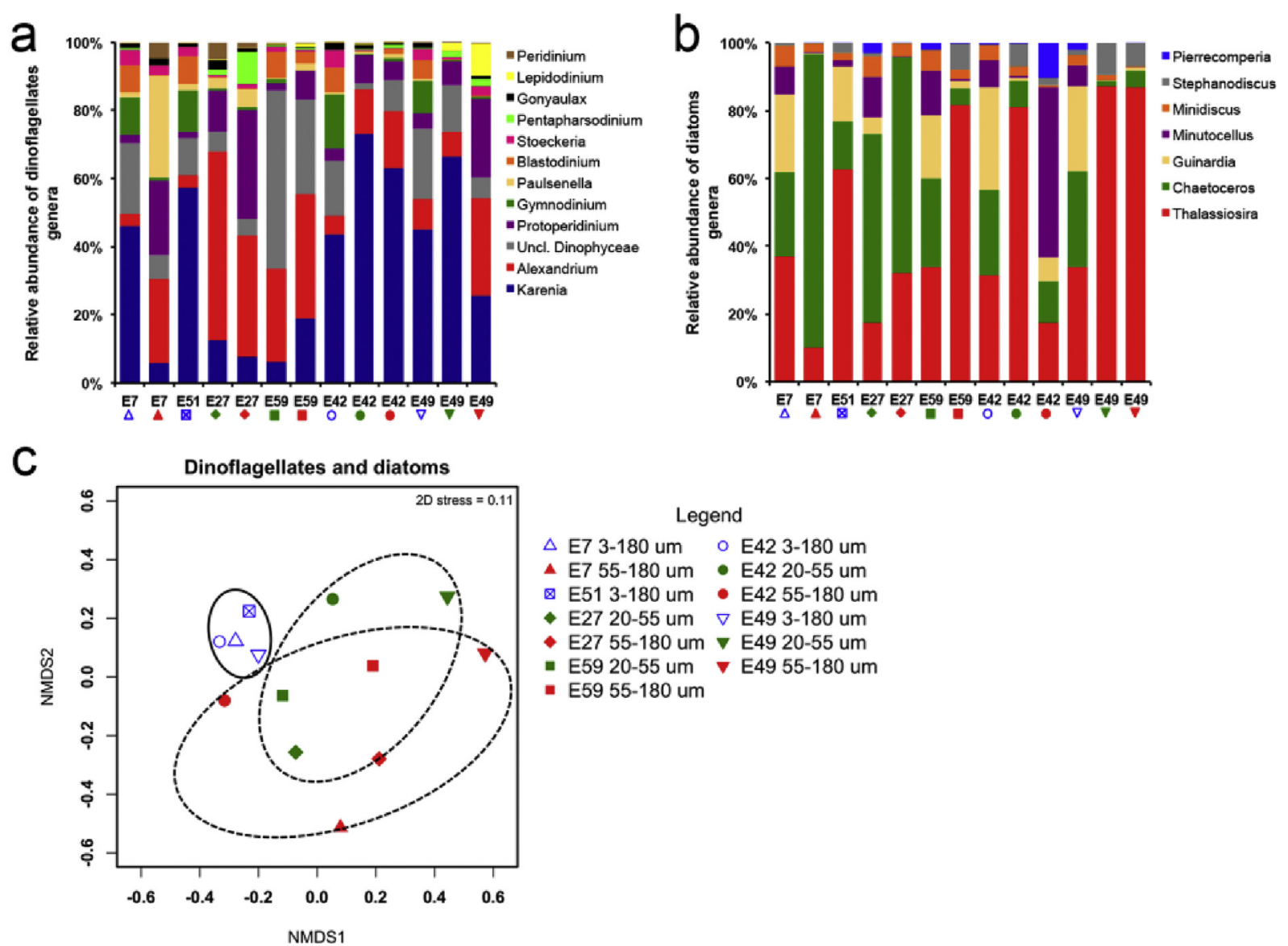

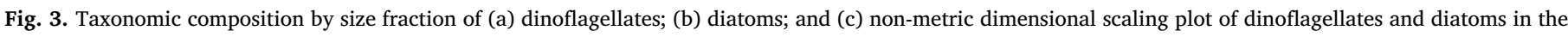

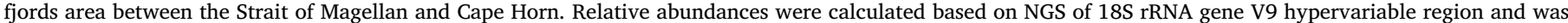

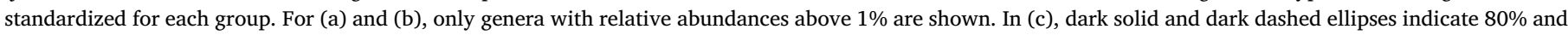
$60 \%$ Bray-Curtis similarity respectively.

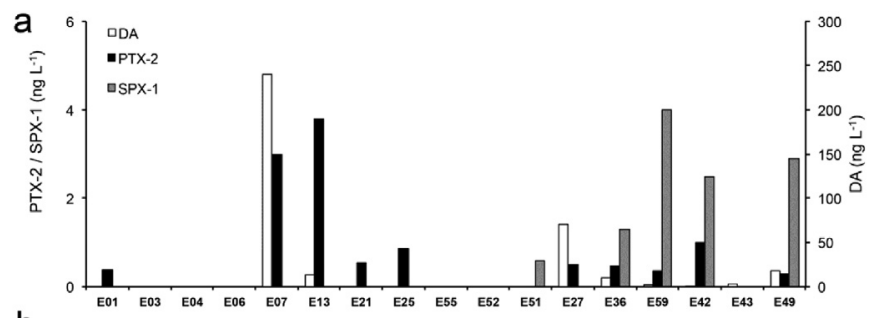

b

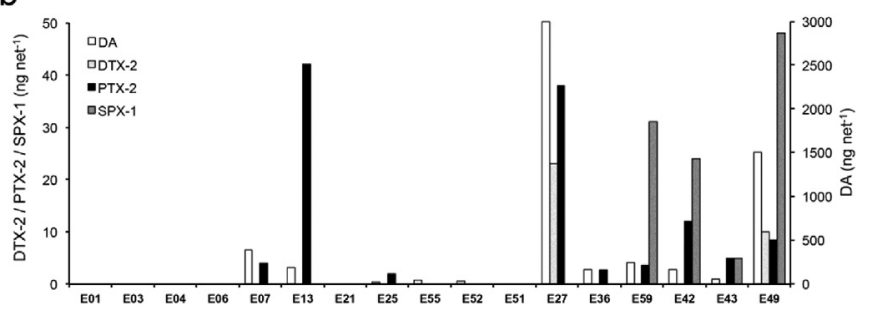

Fig. 4. Toxins detected in (a) the $3-180 \mu \mathrm{m}$ size fractions of surface seawater samples and (b) the $20-55 \mu \mathrm{m}$ net haul fractions. Toxins concentrations were determined by LC-MS/MS. DA: domoic acid, DTX-2: dinophysistoxin-2, PTX-2: pectenotoxin-2 and SPX-1: 13-desmethyl spirolide C.

suggesting that these cells were present at very low abundances.

NMDS analysis performed on dinoflagellate and diatom communities (Fig. 3c), revealed a clustering of samples according to the sample type at the genus level, and this was statistically significant (PERMANOVA, $p=0.006$ ). As in the analysis with the complete plankton community (see Fig. 2c), no clustering was observed by sampling station. Similar results were obtained at the species level (data not shown).

Together, the utilization of microscopy and NGS based on the 18S rRNA gene V9 hypervariable region allowed us to perform a complete taxonomic characterization of the plankton community between the Strait of Magellan and Cape Horn. Knowing that identification and coverage substantially differ between both approaches, advantages and disadvantages of $18 \mathrm{~S}$ rRNA based identification are taken in consideration here. Three important aspect concerning the use of 18S rRNA should be highlighted (1) the current sequencing fragment length $(\sim 200 \mathrm{bp})$ still does not allow a complete coverage of the 18S rRNA gene and thus, taxonomic assignment should be taken with caution; (2) it is well knowing that for certain groups of phytoplankton, not just those that are toxic, the 18S rRNA does not have sufficient resolution for taxonomic discrimination between closely related species; and (3) the high variation of 18S rRNA copy number in marine phytoplankton species, varying from one to hundreds of thousands copies per cell (Zhu et al., 2005). Probably these elements continue limiting the application of this methodology in routine phytoplankton analysis approaches (Dzhembekova et al., 2017).

\subsection{Phycotoxin profiles of field planktonic samples}

Phycotoxins detected in surface seawater samples include the hydrophilic toxin DA and the lipophilic toxins, SPX-1 and PTX-2 (Fig. 4a).

Other lipophilic toxins, such as YTX, GYM, OA and AZAs were not detected. PSTs were not analyzed due to low biomass availability. Detection limits of the analyzed toxins are listed in Table 3. 
Table 3

Limits of detection (LOD) of lipophilic phycotoxins analyzed in this study expressed in $\mathrm{ng} \mathrm{L}^{-1}$ seawater for Niskin bottle samples and in $\mathrm{ng}$ net ${ }^{-1}$ for net tow fractions.

\begin{tabular}{lll}
\hline Toxin & LOD $\left(\mathrm{ng} \mathrm{L}^{-1}\right)$ & LOD $\left(\mathrm{ng} \mathrm{net}^{-1}\right)$ \\
\hline Domoic acid (DA) & 2.8 & 28 \\
13-desmethyl spirolide C (SPX-1) & 0.14 & 1.4 \\
Pectenotoxin-2 (PTX-2) & 0.34 & 3.4 \\
Yessotoxin (YTX) & 0.98 & 9.8 \\
Gymnodimine A (GYM) & 0.011 & 0.11 \\
Okadaic acid (OA) & 2.6 & 26 \\
Dinophysistoxin-1 (DTX-1) & 2.1 & 21 \\
Azaspiracid-1 (AZA-1) & 0.02 & 0.21 \\
\hline
\end{tabular}

DA was the most abundant toxin - detected at most stations - with values between 1.1 and $240 \mathrm{ng} \mathrm{L}^{-1}$ (Table S5). In contrast, concentrations of the other phycotoxins detected proved to be one to three orders of lower magnitude (Fig. 4a). SPX-1 was quantified with values between $0.58 \mathrm{ng} \mathrm{L}^{-1}$ at station E51 and $4.0 \mathrm{ng} \mathrm{L}^{-1}$ at station E59 (Table S5). To the best of our knowledge, this toxin was detected for the first time in phytoplankton samples, both in the study area, as well as in the rest of the Chilean coastal and inland waters, although it was already founded in the bivalves Mesodesma donacium and Mulinia edulis from Northern Chile (Álvarez et al., 2010). PTX-2 was also detected at low concentrations, in the range of $0.30 \mathrm{ng} \mathrm{L}^{-1}$ at station E49 and $3.8 \mathrm{ng} \mathrm{L}^{-1}$ at station E13 (Fig. 4a, Table S5).

To lower the threshold for toxin detection, net haul size fractionated samples (fractions $20-55 \mu \mathrm{m}, 55-180 \mu \mathrm{m},>180 \mu \mathrm{m}$ ), were also analyzed, allowing the detection of all the above-mentioned toxins, in addition to DTX-2, that was not found in the non-concentrated seawater samples. The levels of the distinct phycotoxins detected in the 20-55 $\mu \mathrm{m}$ fraction are shown in Fig. $4 \mathrm{~b}$, as almost all toxigenic species were retained in this size fraction. The absolute toxin amounts were far lower than those of DA and their occurrences were very variable among stations and size fractions, without clear pattern among size fractions (Table S5). In the case of DA, the highest concentration was found in the $>180 \mu \mathrm{m}$ fraction (i.e. $8.4 \mathrm{mg} \mathrm{net}^{-1}$ in E27), although in the rest of the stations, the highest concentrations were found in the fraction of $55-180 \mu \mathrm{m}$. This suggests a trophic transfer from the producer organism to other planktonic species. Additionally, clogging of filters during filtration process and/or artifacts due to chains formation of Pseudonitzschia, cannot be neglected (Brewin et al., 2013). For the rest of the identified phycotoxins the highest concentrations were generally found in the $55-180 \mu \mathrm{m}$ fractions (Fig. S2).

Toxins detected in seawater samples $(3-180 \mu \mathrm{m}$ fractions) and $20-55 \mu \mathrm{m}$ fractions of vertical net haul samples were consistent and generally indicated that stations close to Cape Horn have higher amounts and diversity of phycotoxins than those closer to Magellan Strait (Fig. 4). It is important to note that unconcentrated seawater samples tend to have a bias towards higher abundant species. In contrast, vertical net hauls can be regarded as more representative for the water column, because they provide an integrative composition of the sampled water column, whereas water samples taken by Niskin bottles represent discrete depths. Plankton smaller than the mesh size of the net (usually $20 \mu \mathrm{m}$ ), however, do not get retained and this may explain the lack of AZAs, which are produced by a small sized dinoflagellate (Krock et al., 2009b). Besides, plankton net hauls are not quantitative in a strict sense, because cell concentrations cannot be related to a certain seawater volume. For these reasons toxin data from net haul and seawater plankton of the same station may result in different compositions.

Cluster analysis based on size fractionated net haul DA concentration (an indication of trophic transfer), showed a relationship between DA concentration in the different fractions and the geographical position of the sampling stations (Fig. 5, see Fig. 1 for sampling stations location), with three well defined groups.

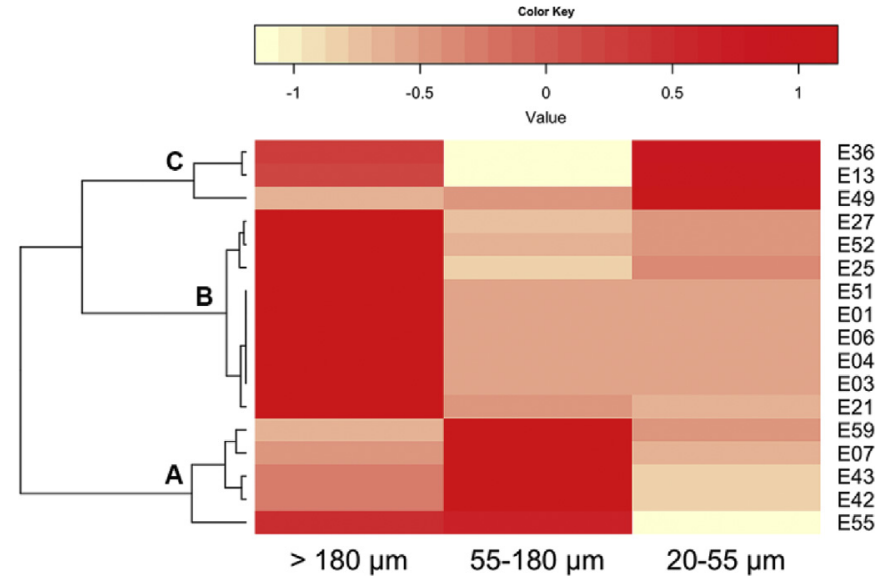

Fig. 5. Heatmap and cluster analysis of DA concentrations in the net haul size fractions (20-55 $\mu \mathrm{m}$; 55-180 $\mu \mathrm{m}$; and $>180 \mu \mathrm{m})$ among stations, using normalized DA values and average linkage clustering based on Euclidean distance. Color intensity represents normalized DA concentrations. (For interpretation of the references to colour in this figure legend, the reader is referred to the Web version of this article.)

Stations that were closer to the Cape Horn grouped together (cluster A in Fig. 5), and stations more inside the Strait of Magellan formed another similarity group (cluster B in Fig. 5). Moreover, stations with a higher influence of oceanic waters, located further outside the fjord area, also clustered together (cluster C in Fig. 5). This clustering could be related with oceanographic differences among stations, however, available physicochemical data, i.e., temperature, salinity, and dissolved oxygen, as well as geographical position (Table S1), were unable to explain the observed clustering (pRDA analysis $p=0.35$ and 0.87 for environmental variables and geographic position respectively; data not shown). This suggests that probably other environmental parameters that were not measured here could be responsible for the observed pattern.

\subsection{Identification of toxigenic species and correspondence with identified phycotoxins}

Microscopy identification of toxigenic species globally agreed with our molecular results using 18S rRNA gene V9 hypervariable region (Table 1, Fig. 3, and Table S4). In support to microscopy and molecular results, the chemical data revealed that the toxin amount in the same phytoplanktonic samples also were very low, confirming a non-bloom situation for all toxigenic species detected.

According to microscopy and NGS approaches, four toxigenic genera were identified: Alexandrium, Dinophysis, Prorocentrum and Pseudo-nitzschia. Consequently, the presence of the respective phycotoxins was confirmed by LC-MS/MS (Fig. 4 and Table S5), with exception of Prorocentrum, which is a known producer of OA and DTX-1. All toxigenic Prorocentrum spp. are benthic dinoflagellates (Lee et al., 2016) and rarely have been observed in higher abundances in the upper water column. This may explain the fact that the genus Prorocentrum was only detected by molecular methods and in low relative abundances $(0.15 \% \pm 0.1$ average of the total reads by sample), without the presence of OA and DTX-1 in the field samples.

On the other hand, an important number of reads were affiliated with the genus Karenia, which resulted to be the most dominant genus within dinoflagellates, particularly $K$. mikimotoi, a known producer of GYM (Seki et al., 1995) $(12.5 \% \pm 14.5$ average of total reads by sample). No microscopy observation of this genus was recorded, probably suggesting an inappropriate taxonomic assignment of the $18 \mathrm{~S}$ rRNA sequence. This is also consistent with the fact that no GYM was detected at any station. 
The genus Alexandrium, second most abundant after Karenia within dinoflagellates, was detected by microscopy (only at two sampling stations) and NGS (at all analyzed stations and size fractions). Alexandrium is a frequent member of the phytoplankton community in the study area, responsible for the recurrent PSTs outbreaks with important social and economic repercussions (Guzmán et al., 2013). The $18 \mathrm{~S}$ rRNA NGS analysis showed A. ostenfeldii was one of the most abundant Alexandrium species. The marine dinoflagellate A. ostenfeldii is the only spirolide-producing organism known till date (Cembella et al., 2000; Kremp et al., 2014). Accordingly, SPX-1 was detected and quantified in low concentrations. Until recently, SPX-1 was considered to be a phycotoxin exclusive from the Northern Hemisphere and New Zealand (Cembella and Krock, 2008). But, trace amounts of SPX-1 had already been found in bivalve samples from Northern Chile, $30^{\circ} 15^{\prime} \mathrm{S}$, $71^{\circ} 30^{\prime} \mathrm{W}$ (Álvarez et al., 2010). In addition, A. ostenfeldii has been previously found in the study area (Lembeye, 2008) and a spirolideproducing strain of $A$. ostenfeldii was isolated from the Beagle Channel (Almandoz et al., 2014). So, our results strongly suggest that this population could be toxic. However, a recently characterized A. ostenfeldii strain from Aysén region (Salgado et al., 2015) shown to produce only PSP toxins, pointing out that further studies on A. ostenfeldii in the fjords area are needed.

The genus Dinophysis was identified in all samples, represented by $D$. acuta and $D$. acuminata. It has been reported that $D$. acuta only produces PTX-2 northward of the $26^{\circ}$ S (Blanco et al., 2007; Fux et al., 2011), and that this species is associated to DTX- 1 at $53^{\circ}$ S of the Magellan Strait (Uribe et al., 2001). The second species, D. acuminata, has been associated to produce DTX- 1 and OA at $46^{\circ} S$ (Zhao et al., 1993), but its toxin profile at higher latitudes is unknown. Here, only DTX-2 was identified and quantified, without the presence of other analogues (Fig. 4). In addition, DTX-1 was detected by Trefault et al. (2011) in planktonic samples only in the North-Western Magellan Strait, whereas PTXs were found along almost the entire Chilean coast, which argues strongly for at least two different toxigenic Dinophysis species being present in South East Pacific coastal waters. Latitudinal differences in toxin profiles in these Dinophysis spp. could be another possible explanation of this apparent incongruence, as has been reported for other sites (Fux et al., 2011; Pizarro et al., 2008).

The genus Pseudo-nitzschia was also detected in all sequenced samples; this genus has a worldwide distribution and is known for producing DA with frequent blooms in the study area (Suárez-Isla et al., 2002). Interestingly, the Pseudo-nitzschia spp. were detected in low abundances by microscopy and molecular analysis, but DA was the most abundant toxin found by LC-MS/MS. This is not surprising, because the genus Pseudo-nitzschia comprises of toxic and non-toxic species, which frequently co-occur (Lelong et al., 2012). In addition, it has been shown that intracellular DA content is induced in Pseudo-nitzschia by the presence of copepods (Haroardóttir et al., 2015). Moreover, interactions with inorganic compounds (i.e. iron, copper, silicate, phosphates and nitrates) have shown to affect the Pseudo-nitzschia growth and the intracellular DA content (Amato et al., 2010; Trick et al., 2010). All these evidences further complicate a direct correlation between Pseudo-nitzschia and DA abundance.

In our best knowledge, this study corresponds to the only description of the plankton community composition by NGS combined with phycotoxins distribution using LC-MS/MS in this sampling area. After eight years of the sampling campaign that originated this dataset, is difficult to extrapolate to the current state of the community composition and phycotoxins. Several factors could be responsible of their variation over time, including temperature, salinity, and nutrient concentrations that are in turn dependent of precipitation, summer melting of adjacent glaciers, and river flow in fjord systems (Avaria, 2008). However, in the context of Global Change we may expect that the increase of water temperature may enhance toxin production and/or growth of HAB species, as has been observed in Pseudo-nitzschia spp. and dinoflagellates. Similarly, anthropogenic influences (i.e., eutrophication, acidification) will likely affect plankton composition, phycotoxin profile, and their distribution in the coming years (reviewed by Fu et al., 2012).

Overall, a good match among toxin-producing species and phycotoxin occurrence was found. Considering the methods applied, the combined approaches used here are still limited for several reasons: (i) toxin profiles are not known yet for all species, (ii) toxin profiles of a given species may vary significantly among different geographic regions, and (iii) relative abundances of taxa based on NGS constitutes a semi-quantitative approach (see above section 3.3). Nevertheless, a complex phytoplankton-phycotoxin pattern was evidenced and new perspectives arose from these findings: What if active microorganisms are targeted? Do the taxonomic diversity and phycotoxin patterns observed here exhibit a temporal variation? With the increasing technology advances of tag sequencing approaches (i.e., accurate copy number estimation and the use of more specific ribosomal marker genes) and the improvement of microbial eukaryotes databases, we expect that in the near future better matches between phycotoxins profiles and community composition will be possible. Thus, chemo- and genetic taxonomic markers would be useful for monitoring systems, alerting the emergence of toxic blooms.

\section{Conclusion}

This study integrates, for the first time, analyses of high-resolution phytoplankton community composition and phycotoxins distribution in fjords from the Southeastern Pacific region, one of the most intensive $\mathrm{HAB}$ areas at a global scale. Altogether, the results presented here reveal a complex phytoplankton-phycotoxin pattern. In one hand, high taxonomic diversity was observed across stations without any apparent spatial pattern of distribution. On the other hand, phycotoxins, particularly DA, showed a patchy distribution and despite good matches obtained when comparing toxin-producing species versus phycotoxin occurrences, no correlation between toxin amounts and relative abundance of the producer organism was found. This may suggest that the analysis of phycotoxins seems to be more accurate in capturing changes inside phytoplankton community, compared to microscopy and NGS (at genus and species level, respectively).

This study constitutes an instantaneous picture of plankton and phycotoxins composition in the area between the Strait of Magellan and the Cape Horn. Thus, a temporal analysis to evaluate the variability of both taxonomic diversity and phycotoxin, in time, should be performed subsequently. Furthermore, a complete analysis of the microbial community, including bacteria and viruses, will allow a better understanding of the complex relationship observed in this study.

\section{Author contributions}

BK; MV and NT conceived the experiments; MM, BK and GP conducted the experiments; MM, BK, RDI, IE and NT analyzed the data; MM, BK, RDI, IE and NT interpreted the data; BK and NT drafted the manuscript. All authors reviewed and approved the final article.

\section{Funding}

This work was funded by projects CONA C16F 10-13 from the Army Hydrographic and Oceanographic Service (Servicio Hidrográfico y Oceanográfico de la Armada- SHOA) and the National Oceanographic Comitee (Comité Oceanográfico Nacional- CONA), Fondef MR07I-1005 and MR10I-1008 and FIDUM 100505. Cooperation between Chilean and German partners was possible through the Programa de Cooperacion Científica Internacional para Proyectos de Intercambio Conicyt- BMBF Convocatoria 2011 (Conicyt Grant \# 2011-504/BMBF Grant \# CHL 11/011(01DN12102)). 


\section{Conflict of interest}

The authors declare that they have no conflict of interest.

\section{Ethical statement}

The authors declare that no animals were used during experimental work and that the methodology used has no ethical implications or biosecurity related. The manuscript complies with the Elsevier Ethical Guidelines for Journal Publication.

\section{Acknowledgements}

We thank the captain and crew of the "Abate Molina", and especially to Roberto Raimapo and César Alarcón, IFOP, Punta Arenas, for the invaluable help in the field sampling procedure. We also thank Annegret Mueller and Wolfgang Drebing, AWI, Bremerhaven, for technical support in the extraction and processing of the samples for LCMS/MS.

\section{Transparency document}

Transparency document related to this article can be found online at http://dx.doi.org/10.1016/j.toxicon.2018.06.078.

\section{Appendix A. Supplementary data}

Supplementary data related to this article can be found at http://dx. doi.org/10.1016/j.toxicon.2018.06.078.

\section{References}

Almandoz, G.O., Montoya, N.G., Hernando, M.P., Benavides, H.R., Carignan, M.O., Ferrario, M.E., 2014. Toxic strains of the Alexandrium ostenfeldii complex in southern South America (Beagle Channel, Argentina). Harmful Algae 37, 100-109. http://dx. doi.org/10.1016/j.hal.2014.05.011.

Álvarez, G., Uribe, E., Ávalos, P., Mariño, C., Blanco, J., 2010. First identification of azaspiracid and spirolides in Mesodesma donacium and Mulinia edulis from Norther Chile. Toxicon 55, 638-641. http://dx.doi.org/10.1016/j.toxicon.2009.07.014.

Alves-de-Souza, C., Gonzalez, M.T., Iriarte, J.L., 2008. Functional groups in marine phytoplankton assemblages dominated by diatoms in fjords of southern Chile. J. Plankton Res. 30, 1233-1243. http://dx.doi.org/10.1093/plankt/fbn079.

Alves-de-Souza, C., Varela, D., Contreras, C., de La Iglesia, P., Fernández, P., Hipp, B., Hernández, C., Riobó, P., Reguera, B., Franco, J.M., Diogène, J., García, C., Lagos, N., 2014. Seasonal variability of Dinophysis spp. and Protoceratium reticulatum associated to lipophilic shellfish toxins in a strongly stratified Chilean fjord. Deep. Res. Part II Top. Stud. Oceanogr. 101, 152-162. http://dx.doi.org/10.1016/j.dsr2.2013.01.014.

Amaral-Zettler, L.A., McCliment, E.A., Ducklow, H.W., Huse, S.M., 2009. A method for studying protistan diversity using massively parallel sequencing of V9 hypervariable regions of small-subunit ribosomal RNA genes. PLoS One 4, 1-9. http://dx.doi.org/ 10.1371/journal.pone.0006372.

Amato, A., Lüdeking, A., Kooistra, W.H.C.F., 2010. Intracellular domoic acid production in Pseudo-nitzschia multistriata isolated from the Gulf of Naples (Tyrrhenian sea, Italy). Toxicon 55, 157-161. http://dx.doi.org/10.1016/j.toxicon.2009.07.005.

Avaria, S., 2008. Phytoplankton in the austral Chilean channels and fjords. In: Silva, N., Palma, S. (Eds.), Progress in the Oceanographic Knowledge of Chilean interior Waters, from Puerto Montt to Cape Horn. Comité Oceanográfico Nacional - Pontificia Universidad Católica de Valparaíso, Valparaíso, pp. 89-92.

Avaria, S., Cáceres, C., Castillo, P., Muñoz, P., 2003. Distribución del microfitoplancton marino en la zona Estrecho de Magallanes-Cabo de Hornos, Chile, en la primavera de 1998 (Crucero CIMAR 3 Fiordos). Cienc. y Tecnol. del Mar, CONA 26, 79-96.

Berdalet, E., Fleming, L.E., Gowen, R., Davidson, K., Hess, P., Backer, L.C., Moore, S.K., Hoagland, P., Enevoldsen, H., 2016. Marine harmful algal blooms, human health and wellbeing: challenges and opportunities in the 21 st century. J. Mar. Biol. Assoc. U. K. 2015, 61-91. http://dx.doi.org/10.1017/S0025315415001733.

Berdalet, E., Montresor, M., Reguera, B., Roy, S., Yamazaki, H., Cembella, A., Raine, R., 2017. Harmful algal blooms in fjords, coastal embayments, and stratified systems: recent progress and future research. Oceanography 30, 46-57. http://dx.doi.org/10. 5670/oceanog. 2017.109.

Blanco, J., Álvarez, G., Uribe, E., 2007. Identification of pectenotoxins in plankton, filter feeders, and isolated cells of a Dinophysis acuminata with an atypical toxin profile, from Chile. Toxicon 49, 710-716. http://dx.doi.org/10.1016/j.toxicon.2006.11.013.

Blanco, J., Moroño, A., Fernández, M.L., 2005. Toxic episodes in shellfish, produced by lipophilic phycotoxins: an overview. Rev. Galega Recur. Mariños (Monog.) 1, 1-70.

Brewin, R.J.W., Sathyendranath, S., Lange, P.K., Tilstone, G., 2013. Comparison of two methods to derive the size-structure of natural populations of phytoplankton. Deep.
Res. Part I Oceanogr. Res. Pap. 85, 72-79. http://dx.doi.org/10.1016/j.dsr.2013.11. 007.

Caporaso, J.G., Lauber, C.L., Walters, W.A., Berg-Lyons, D., Huntley, J., Fierer, N., Owens, S.M., Betley, J., Fraser, L., Bauer, M., Gormley, N., Gilbert, J.A., Smith, G., Knight, R., 2012. Ultra-high-throughput microbial community analysis on the Illumina HiSeq and MiSeq platforms. ISME J. 6, 1621-1624. http://dx.doi.org/10.1038/ismej. 2012.8.

Cembella, A., Krock, B., 2008. Cyclic imine toxins: chemistry, biogeography, biosynthesis and pharmacology. In: Botana, L.,M. (Ed.), Seafood and Freshwater Toxins: Pharmacology, Physiology, and Detection. CRC Press, Boca Raton, pp. 561-580.

Cembella, A.D., Lewis, N.I., Quilliam, M.A., 2000. The marine dinoflagellate Alexandrium ostenfeldii (Dinophyceae) as the causative organism of spirolide shellfish toxins. Phycologia 39, 67-74. http://dx.doi.org/10.2216/i0031-8884-39-1-67.1.

Cheng, J., Galili, T., Bostock, M., Palmer, J., 2016. d3heatmap: Interactive Heat Maps Using "htmlwidgets" and "D3.Js" Package. R package Version 0.6.1.1, 2016.

Doyle, J.J., Doyle, J.L., 1987. A rapid DNA isolation procedure for small quantities of fresh leaf tissue. Phytochem. Bull. 19, 11-15.

Drebes, G., Kfihn, S.F., Gmelch, A., Schnepf, E., 1996. Cryothecomonas aestivalis sp. nov., a colourless nanoflagellate feeding on the marine centric diatom Guinardia delicatula (Cleve) Hasle. Helgol. Meeresunters. 497-515. http://dx.doi.org/10.1007/ BF02367163.

Dzhembekova, N., Urusizaki, S., Moncheva, S., Ivanova, P., Nagai, S., 2017. Applicability of massively parallel sequencing on monitoring harmful algae at Varna Bay in the Black Sea. Harmful Algae 68, 40-51. http://dx.doi.org/10.1016/j.hal.2017.07.004.

Edgar, R.C., Haas, B.J., Clemente, J.C., Quince, C., Knight, R., 2011. UCHIME improves sensitivity and speed of chimera detection. Bioinformatics 27, 2194-2200. http://dx. doi.org/10.1093/bioinformatics/btr381.

Egas, C., Henriquez-Castillo, C., Delherbe, N., Molina, E., Dos Santos, A.L., Lavin, P., De La Iglesia, R., Vaulot, D., Trefault, N., 2017. Short timescale dynamics of phytoplankton in Fildes Bay, Antarctica. Antarct. Sci. 29, 217-228. http://dx.doi.org/10. 1017/S0954102016000699.

Elferink, S., Neuhaus, S., Wohlrab, S., Toebe, K., Voß, D., Gottschling, M., Lundholm, N., Krock, B., Koch, B.P., Zielinski, O., Cembella, A., John, U., 2017. Molecular diversity patterns among various phytoplankton size-fractions in West Greenland in late summer. Deep-Sea Res. Part I Oceanogr. Res. Pap. 121, 54-69.

Fu, F.X., Tatters, A.O., Hutchins, D.A., 2012. Global change and the future of harmful algal blooms in the ocean. Mar. Ecol. Prog. Ser. 470, 207-233. http://dx.doi.org/10. 3354/meps10047.

Fux, E., Smith, J.L., Tong, M., Guzmán, L., Anderson, D.M., 2011. Toxin profiles of five geographical isolates of Dinophysis spp. from North and South America. Toxicon 57, 275-287. http://dx.doi.org/10.1016/j.toxicon.2010.12.002.

Gilbert, J.A., Jansson, J.K., Knight, R., 2014. The Earth Microbiome project: successes and aspirations. BMC Biol. 12, 69. http://dx.doi.org/10.1186/s12915-014-0069-1.

Guillou, L., Bachar, D., Audic, S., Bass, D., Berney, C., Bittner, L., Boutte, C., Burgaud, G., De Vargas, C., Decelle, J., Del Campo, J., Dolan, J.R., Dunthorn, M., Edvardsen, B., Holzmann, M., Kooistra, W.H.C.F., Lara, E., Le Bescot, N., Logares, R., Mahé, F., Massana, R., Montresor, M., Morard, R., Not, F., Pawlowski, J., Probert, I., Sauvadet, A.L., Siano, R., Stoeck, T., Vaulot, D., Zimmermann, P., Christen, R., 2013. The Protist Ribosomal Reference database (PR2): a catalog of unicellular eukaryote Small SubUnit rRNA sequences with curated taxonomy. Nucleic Acids Res. 41, 597-604. http://dx.doi.org/10.1093/nar/gks1160.

Guzmán, L., Vivanco, X., Pizarro, G., Vidal, G., Arenas, V., Iriarte, L., Mercado, S. Alarcón, C., Pacheco, H., Palma, M., 2013. Relative abundance as a tool to increase the certainty of temporal and spatial distribution of of harmful algal species. In: Pagou, P., Hallegraeff, G. (Eds.), Proceedings of the 14th International Conference on Harmful Algae. International Society for the Study of Harmful Algae and Intergovernmental Oceanographic Commission of UNESCO 2013, pp. 257-259.

Haroardóttir, S., Pančić, M., Tammilehto, A., Krock, B., Møller, E.F., Nielsen, T.G., Lundholm, N., 2015. Dangerous relations in the arctic marine food web: interactions between toxin producing Pseudo-nitzschia diatoms and Calanus copepodites. Mar. Drugs 13, 3809-3835. http://dx.doi.org/10.3390/md13063809.

Hess, P., 2010. Requirements for screening and confirmatory methods for the detection and quantification of marine biotoxins in end-product and official control. Anal. Bioanal. Chem. 397, 1683-1694. http://dx.doi.org/10.1007/s00216-009-3444-y.

Iriarte, J.L., González, H.E., Nahuelhual, L., 2010. Patagonian fjord ecosystems in Southern Chile as a highly vulnerable region: problems and needs. Ambio 39, 463-466. http://dx.doi.org/10.1007/s13280-010-0049-9.

Iriarte, J.L., Kusch, A., Osses, J., Ruiz, M., Iriarte, J.L., 2001. Phytoplankton biomass in the sub-Antarctic area of the Straits of Magellan $\left(53^{\circ} \mathrm{S}\right)$, Chile during spring-summer 1997/1998. Polar Biol. 24, 154-162. http://dx.doi.org/10.1007/s003000000189.

Kremp, A., Tahvanainen, P., Litaker, W., Krock, B., Suikkanen, S., Leaw, C.P., Tomas, C., 2014. Phylogenetic relationships, morphological variation, and toxin patterns in the Alexandrium ostenfeldii (Dinophyceae) complex: implications for species boundaries and identities. J. Phycol. 50, 81-100. http://dx.doi.org/10.1111/jpy.12134.

Krock, B., Seguel, C.G., Valderrama, K., Tillmann, U., 2009a. Pectenotoxins and yessotoxin from Arica Bay, North Chile as determined by tandem mass spectrometry. Toxicon 54, 364-367. http://dx.doi.org/10.1016/j.toxicon.2009.04.013.

Krock, B., Tillmann, U., John, U., Cembella, A., 2008. LC-MS-MS aboard ship: tandem mass spectrometry in the search for phycotoxins and novel toxigenic plankton from the North Sea. Anal. Bioanal. Chem. 392, 797-803. http://dx.doi.org/10.1007/ s00216-008-2221-7.

Krock, B., Tillmann, U., John, U., Cembella, A.D., 2009b. Characterization of azaspiracids in plankton size-fractions and isolation of an azaspiracid-producing dinoflagellate from the North Sea. Harmful Algae 8, 254-263. http://dx.doi.org/10.1016/j.hal. 2008.06.003.

Larsen, A., Tanaka, T., Zubkov, M.V., Thingstad, T.F., 2008. P-affinity measurements of 
specific osmotroph populations using cell-sorting flow cytometry. Limnol Oceanogr. Meth. 6, 355-363. http://dx.doi.org/10.4319/lom.2008.6.355.

Lee, T., Fong, F., Ho, K.-C., Lee, F., 2016. The mechanism of diarrhetic shellfish poisoning toxin production in Prorocentrum spp.: physiological and molecular perspectives. Toxins 8, 272. http://dx.doi.org/10.3390/toxins8100272.

Lelong, A., Hégaret, H., Soudant, P., Bates, S.S., 2012. Pseudo-nitzschia (Bacillariophyceae) species, domoic acid and amnesic shellfish poisoning: revisiting previous paradigms. Phycologia 51, 168-216. http://dx.doi.org/10.2216/11-37.1.

Lembeye, G., 2008. Harmful algal blooms in the austral Chilean channels and fjords. In: Silva, N., Palma, S. (Eds.), Progress in the Oceanographic Knowledge of Chilean interior Waters, from Puerto Montt to Cape Horn. Comité Oceanográfico Nacional Pontificia Universidad Católica de Valparaíso, Valparaíso, pp. 99-103.

Martin, M., 2011. Cutadapt removes adapter sequences from high-throughput sequencing reads. EMBnet.j. 17, 10. http://dx.doi.org/10.14806/ej.17.1.200.

Massana, R., 2011. Eukaryotic picoplankton in surface oceans. Annu. Rev. Microbiol. 65, 91-110. http://dx.doi.org/10.1146/annurev-micro-090110-102903.

Oksanen, J., Blanchet, F.G., Kindt, R., Legendre, P., Minchin, P.R., O'Hara, R.B., Simpson, G.L., Solymos, P., Stevens, M.H.H., Wagner, H., 2016. Vegan: Community Ecology Package. R Package Version 2.3-3, 2016.

Park, M.G., Yih, W., Coats, D.W., 2004. Parasites and phytoplankton, with special emphasis on dinoflagellate infections. J. Eukaryot. Microbiol. 51, 145-155. http://dx. doi.org/10.1111/j.1550-7408.2004.tb00539.x.

Pawlowski, J., Christen, R., Lecroq, B., Bachar, D., Shahbazkia, H.R., Amaral-Zettler, L., Guillou, L., 2011. Eukaryotic richness in the abyss: insights from pyrotag sequencing. PLoS One 6. http://dx.doi.org/10.1371/journal.pone.0018169.

Pizarro, G., Paz, B., Franco, J.M., Suzuki, T., Reguera, B., 2008. First detection of Pectenotoxin-11 and confirmation of OA-D8 diol-ester in Dinophysis acuta from European waters by LC-MS/MS. Toxicon 52, 889-896. http://dx.doi.org/10.1016/j. toxicon.2008.09.001.

Pruesse, E., Quast, C., Knittel, K., Fuchs, B.M., Ludwig, W., Peplies, J., Glockner, F.O., 2007. SILVA: a comprehensive online resource for quality checked and aligned ribosomal RNA sequence data compatible with ARB. Nucleic Acids Res. 35, 7188-7196. http://dx.doi.org/10.1093/nar/gkm864.

Quast, C., Pruesse, E., Yilmaz, P., Gerken, J., Schweer, T., Yarza, P., Peplies, J., Glöckner, F.O., 2013. The SILVA ribosomal RNA gene database project: improved data processing and web-based tools. Nucleic Acids Res. 41, 590-596. http://dx.doi.org/10. 1093/nar/gks1219.

R Core Team. R, 2014. A Language and Environment for Statistical Computing. R Foundation for Statistical Computing, Vienna, Austria.

Rasmussen, S.A., Andersen, A.J.C., Andersen, N.G., Nielsen, K.F., Hansen, P.J., Larsen, T.O., 2016. Chemical diversity, origin, and analysis of phycotoxins. J. Nat. Prod. 79, 662-673. http://dx.doi.org/10.1021/acs.jnatprod.5b01066.

Richards, T.A., Jones, M.D.M., Leonard, G., Bass, D., 2012. Marine fungi: their ecology and molecular diversity. Annu. Rev. Mar. Sci. 4, 495-522. http://dx.doi.org/10. 1146/annurev-marine-120710-100802.

Salgado, P., Riobó, P., Rodríguez, F., Franco, J.M., Bravo, I., 2015. Differences in the toxin profiles of Alexandrium ostenfeldii (Dinophyceae) strains isolated from different geographic origins: evidence of paralytic toxin, spirolide, and gymnodimine. Toxicon 103, 85-98. http://dx.doi.org/10.1016/j.toxicon.2015.06.015.

Schloss, P.D., Westcott, S.L., Ryabin, T., Hall, J.R., Hartmann, M., Hollister, E.B., Lesniewski, R.A., Oakley, B.B., Parks, D.H., Robinson, C.J., Sahl, J.W., Stres, B., Thallinger, G.G., Van Horn, D.J., Weber, C.F., 2009. Introducing mothur: open- source, platform-independent, community-supported software for describing and comparing microbial communities. Appl. Environ. Microbiol. 75, 7537-7541. http:// dx.doi.org/10.1128/AEM.01541-09.

Seki, T., Satake, M., Mackenzie, L., Kaspar, H.F., Yasumoto, T., 1995. Gymnodimine, a new marine toxin of unprecedented structure isolated from New Zealand oysters and the dinoflagellate, Gymnodinium sp. Tetrahedron Lett. 36, 7093-7096. http://dx.doi. org/10.1016/0040-4039(95)01434-J.

Sjöqvist, C.O., Lindholm, T.J., 2011. Natural co-occurrence of Dinophysis acuminata (Dinoflagellata) and Mesodinium rubrum (Ciliophora) in thin layers in a coastal inlet. J. Eukaryot. Microbiol. 58, 365-372. http://dx.doi.org/10.1111/j.1550-7408.2011. 00559.x.

Suárez-Isla, B., López, A., Clément, A., Guzmán, L., 2002. Estudios recientes sobre floraciones de algas nocivas y toxinas marinas en las costas de Chile. In: Sar, M.E., Ferrario, M., Reguera, B. (Eds.), Floraciones Algales Nocivas en el Cono Sur Americano. Instituto Español de Oceanografía, Madrid, España, pp. 257-268.

Toebe, K., Joshi, A.R., Messtorff, P., Tillmann, U., Cembella, A., John, U., 2013. Molecular discrimination of taxa within the dinoflagellate genus Azadinium, the source of azaspiracid toxins. J. Plankton Res. 35, 225-230. http://dx.doi.org/10.1093/plankt/ fbs077.

Trefault, N., Krock, B., Delherbe, N., Cembella, A., Vásquez, M., 2011. Latitudinal transects in the southeastern Pacific Ocean reveal a diverse but patchy distribution of phycotoxins. Toxicon 58, 389-397. http://dx.doi.org/10.1016/j.toxicon.2011.07. 006.

Trick, C.G., Bill, B.D., Cochlan, W.P., Wells, M.L., Trainer, V.L., Pickell, L.D., 2010. Iron enrichment stimulates toxic diatom production in high-nitrate, low-chlorophyll areas. Proc. Natl. Acad. Sci. U. S. A. 107, 5887-5892. http://dx.doi.org/10.1073/ pnas.0910579107.

Ugalde, J.A., Gallardo, M.J., Belmar, C., Muñoz, P., Ruiz-Tagle, N., Ferrada-Fuentes, S., Espinoza, C., Allen, E.E., Gallardo, V.A., 2013. Microbial life in a fjord: metagenomic analysis of a microbial mat in chilean Patagonia. PLoS One 8, 1-11. http://dx.doi. org/10.1371/journal.pone.0071952.

Uribe, J.C., García, C., Rivas, M., Lagos, N., 2001. First report of diarrhetic shellfish toxins in magellanic fjords, southern Chile. J. Shellfish Res. 20, 69-74.

Utermöhl, H., 1958. Zur Vervollkomnung der quantitativen Phytoplankton-Methodik. Mitt. int. Ver. ther. angew. Limnol. 9, 1-38.

Vaulot, D., Eikrem, W., Viprey, M., Moreau, H., 2008. The diversity of small eukaryotic phytoplankton $(\leq 3 \mu \mathrm{m})$ in marine ecosystems. FEMS Microbiol. Rev. 32, 795-820. http://dx.doi.org/10.1111/j.1574-6976.2008.00121.x.

Vaulot, D., Lepère, C., Toulza, E., De la Iglesia, R., Poulain, J., Gaboyer, F., Moreau, H., Vandepoele, K., Ulloa, O., Gavory, F., Piganeau, G., 2012. Metagenomes of the picoalga Bathycoccus from the Chile coastal upwelling. PLoS One 7, e39648. http://dx. doi.org/10.1371/journal.pone.0039648.

Warnes, G.R., Bolker, B., Bonebakker, L., Gentleman, R., Huber, W., Liaw, A., Lumley, T., Maechler, M., Magnusson, A., Moeller, S., Schwartz, M., Venables, B., 2016. Gplots: Various R Programming Tools for Plotting Data Description Package. R package Version 3.0.1, 2016.

Zhao, J., Lembeye, G., Cenci, G., Wall, B., Yasumoto, T., 1993. Determination of okadaic acid and Dinophysistoxin-1 in mussels from Chile, Italy and Ireland. In: Smayda, T.J., Shimizu, Y. (Eds.), Toxic Phytoplankton Bloom in the Sea. Elsevier, pp. 587-592.

Zhu, F., Massana, R., Not, F., Marie, D., Vaulot, D., 2005. Mapping of picoeucaryotes in marine ecosystems with quantitative PCR of the 18S rRNA gene. FEMS Microbiol. Ecol. 52, 79-92. http://dx.doi.org/10.1016/j.femsec.2004.10.006. 